\title{
Opening Doors Using Internet Of Things (IoT) Based Face Recognition
}

\author{
Wahyu Ariansyah ${ }^{1}$, Dirja Nur Ilham ${ }^{2 *}$, Khairuman $^{3}$, Rudi Arif Candra ${ }^{4}$ \\ 1,2,3,4 Politeknik Aceh Selatan, Indonesia \\ 1ariansyahcr5@gmail.com, ${ }^{2}$ dirja.poltas@gmail.com, ${ }^{3}$ khairuman@poltas.ac.id, ${ }^{4}$ rudiarifcandra@gmail.com
}

open

access

*Corresponding Author

Article History:

Submitted: 15 September 2021

Accepted: 17 Oktober 2021

Published: 26 November 2021

Keywords:

Face Recognition; Esp32 Cam;

NodeMCU; Relay; Solenoid.

Brilliance: International

Journal of Artificial

Intelligenceis licensed under a

Creative Commons Attribution-

NonCommercial 4.0 International

(CC BY-NC 4.0).

\begin{abstract}
Face recognition is a digital image processing approach that uses face photographs as input to identify a person. Face recognition is important since the face is a person's primary means of identification because the shape of a person's face differs significantly, which is easy to do intuitively using the visual senses. Image processing, face detection, feature extraction, and classification are all aspects of the face recognition system, which seeks to determine whether the image obtained is a person's face stored in the database. Principles of operation If a human face appears in front of the camera, the system quickly executes a facial recognition procedure and compares the face to facial data kept on the website. If a face detected by the camera matches the face stored on the website, the solenoid will automatically be in the on position or the door will be open, and vice versa, if the face detected by the camera does not match, the solenoid will remain in the off position or the door will remain locked. This tool can be used to improve the security system on the door of a private room or a room that can only be accessed by certain people.
\end{abstract}

\section{INTRODUCTION}

Face recognition is one of the pattern recognition techniques that use faces as input to make the security system stronger. Face recognition was first created in 1960, employing a variety of methodologies and techniques that were available at the time (Sahfitri \& Simanjuntak, 2021). This method seeks to create a reliable individual identification process with the highest level of security, making it impossible for thieves to break in. Face recognition is a digital image processing approach for identifying a person using face photographs recorded on a web server as input. Several digital image processing techniques are currently well-known in terms of technology that keeps up with the times and can be used to identify the identity of the owner of the facial image, making the security system more secure (Setiawan, Jaenul, \& Priyokusumo, 2020). and much more face detection research using various approaches and technologies, including Facial recognition has been the focus of countless past investigations, including the use of the Viola-Jones method in a face detection system (Sahfitri \& Simanjuntak, 2021). Prototype of home security system using face recognition based on raspberry Pi 4 (Setiawan et al., 2020). Home security system through facial recognition using Raspberry Pi-based Webcam and Opencv Library (Sutarti, Samsuni, \& Asseghaf, 2019). Home door security system with face recognition based on internet of things (Rosa, Clara Feridda, Riski Amelia, 2019). The Hidden Markov model (HMM) method is used in the face recognition system (Dodi Sudiana, Arman D. Diponegoro, n.d.). Real-Time Facial Recognition System with Adaboost, Eigenface PCA \& MySQL (Suprianto, 2013). Face Recognition Based Door Security System Using Fisherface Method (Susanto, Purnomo, \& Fahmi, 2017). Face Recognition-Based Attendance System with LBPH Method Using Raspberry Pi (Bustomi, Hariyanto, \& Kunci, 2020). Implementation of Face Recognition on Wheeled Robot (Panekenan et al., 2019).

Many other researchers have conducted similar research on the application of the internet of things, such as The Infusion of Notification Design With an Application of Social Media Based on an Internet of Things (IoT) (Candra, Saputra, Ilham, Setiawan, \& Hardisal, 2020). Designing an Arduino-based Automatic Cocoa Fermentation Tool (Balkhaya, Ilham, Candra, Hardisal, \& Hasbaini, 2020). Light Control Design by Using Social Media Telegram Applications Based on Internet Of Things (IoT) (Candra, Ilham, Hardisal, \& Sriwahyuni, 2019). Design of an Automatic Water Pump on a Traditional Boat (Ihsan, Ilham, Candra, Yunan, \& Hardisal, 2020). Heart Rate Monitoring and Stimulation with the Internet of Thing-Based (IoT) Al Quran Recitation (Ilham, Hardisal, Balkhaya, Candra, \& Sipahutar, 2019). Rain Monitoring System for Nutmeg Drying Based on Internet of Things (Ilham, Satria, Anugreni, Candra, \& Kusumo, 2021).

Based on the foregoing, this research will develop a prototype of the Opening Doors Using Face Recognition Based on the Internet of Things (IoT) for privacy spaces, which will read facial features that have been previously inputted and stored on the webserver, allowing only the stored faces to activate the solenoid, allowing the door to open. 


\section{LITERATURE REVIEW}

Facial recognition has been the focus of countless past investigations, including the use of the Viola-Jones method in a face detection system (Sahfitri \& Simanjuntak, 2021). Prototype of home security system using face recognition based on raspberry Pi 4 (Setiawan et al., 2020). Home security system through facial recognition using Raspberry Pi-based Webcam and Opencv Library (Sutarti et al., 2019). Home door security system with face recognition based on internet of things (Rosa, Clara Feridda, Riski Amelia, 2019). The Hidden Markov model (HMM) method is used in the face recognition system (Dodi Sudiana, Arman D. Diponegoro, n.d.). Real-Time Facial Recognition System with Adaboost, Eigenface PCA \& MySQL (Suprianto, 2013). Face Recognition Based Door Security System Using Fisherface Method (Susanto et al., 2017). Face Recognition-Based Attendance System with LBPH Method Using Raspberry Pi (Bustomi et al., 2020). Implementation of Face Recognition on Wheeled Robot (Panekenan et al., 2019).

\section{METHOD}

Tools and materials needed in the system Opening the Door Using Face Recognition To Access the Privacy Room Using Arducam Esp32 Based On The Internet Of Things (IoT). consists of hardware and software, namely:

Hardware

The hardware used includes:

Table 1. System Hardware

\begin{tabular}{cll}
\hline Number & \multicolumn{1}{c}{ Name } & \multicolumn{1}{c}{ Function } \\
\hline & & As a place to run applications in the system Open Doors Using \\
1 & Computer with windows 10 & $\begin{array}{l}\text { Face Recognition To Access Privacy Rooms Using Arducam } \\
\text { Esp32 Based On The Internet Of Things (IoT). } \\
\text { As a controller of the components in the system Opening the }\end{array}$ \\
& & $\begin{array}{l}\text { Door Using Face Recognition To Access the Privacy Room Using } \\
\text { Arducam Esp32 Based On The Internet Of Things (IoT). }\end{array}$ \\
2 & NodeMCU ESP32 & As a liaison between one component and another. \\
3 & Jumper Cable & As an automatic switch \\
4 & Relay 2 Channel & As a current provider for the system \\
6 & Power Supply & As opening and closing the door \\
\hline
\end{tabular}

\section{Software}

The software used in this research are:

Table 2. Software and versions

\begin{tabular}{clc}
\hline Number & \multicolumn{1}{c}{ Name } & Specifications (Version) \\
\hline 1 & Blynk & 2.27 .15 \\
2 & Arduino IDE & 1.8 .5 \\
3 & Fritzing & $0.9 .2 \mathrm{~b}$ \\
\hline
\end{tabular}

\section{Chart of Design}

Information:

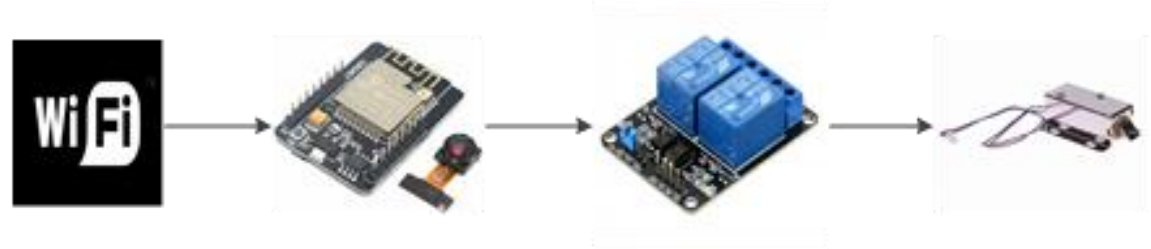

Figure 1: Schematic Diagram

1. Wifi can be used as a hotspot for information.

2. The Nodemcu Esp32 is a camera controller as well as a driver.

3. The Lock Door also serves as a door opener.

4. The Relay 2 Channel serves as a switch. 


\section{System design}

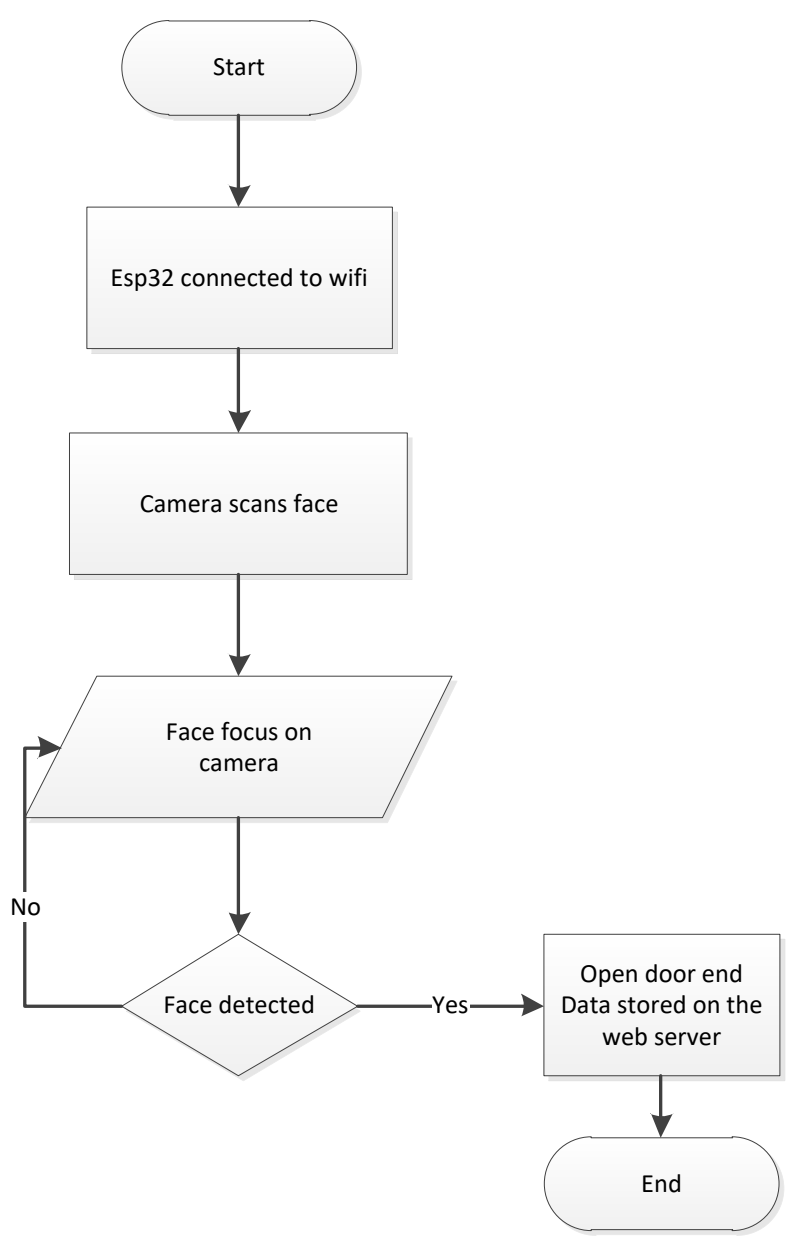

Figure 2. System Design

Based on Figure 1. The flowchart shows that when the system starts up, the Esp32 NodeMCU will be connected to the wifi/network, and the camera will begin scanning the user's face. If the facial data in the database read by the camera matches the facial data in the database, the relay, which acts as a switch, will turn on. and the door will open on its own.

\section{Designing Tools}

When all of the components are connected, the system will begin to run. When the system starts, the NodeMCU Esp32 will be connected to the wifi/network, and the camera will begin scanning the user's face. If the user's face matches the database that the camera has read, relays that function as switches will turn on, and the door will open automatically.

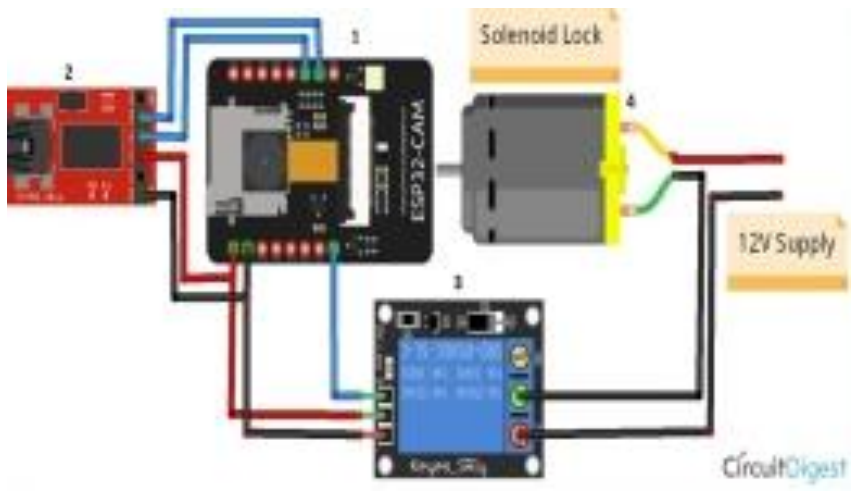

Figure 3. shows the tool design 


\section{Information:}

1. Esp 32 cam has a camera module that recognizes patterns on faces and is used to operate all components.

2. On the Esp 32 Cam module, the USB Tool serves as a program uploader.

3. The automatic switch Relay 2 Channel is used for.

4. A lock Door is a door opener that works automatically.

\section{Sketch of a Tool}

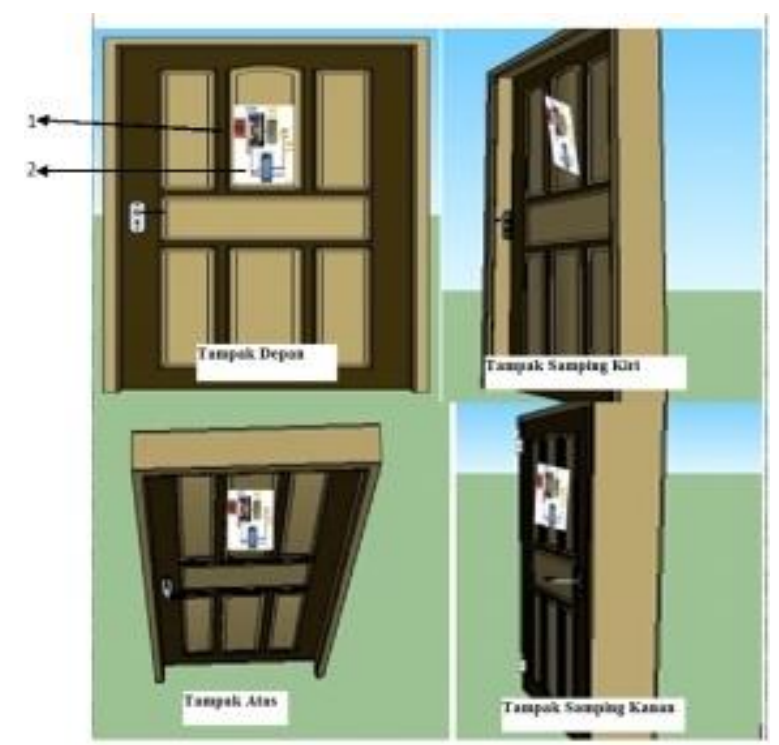

Figure 4. Sketch of a Tool

\section{Face Registration Stage ( Face recorder )}

\section{RESULT}

After the circuit is set up, the first step is to upload the program to the ESP32 Camera board. Once the program is uploaded, the camera module must click the reset button to connect to a hotspot or wifi network for the first time and show the camera's IP address. In this situation, a connection to this wifi network is required to visit the camera website, which may be done by copying and pasting the IP address from the Arduino software serial monitor into Google Chrome with the IP 192.168.43.125, and then performing face recording on the webpage.

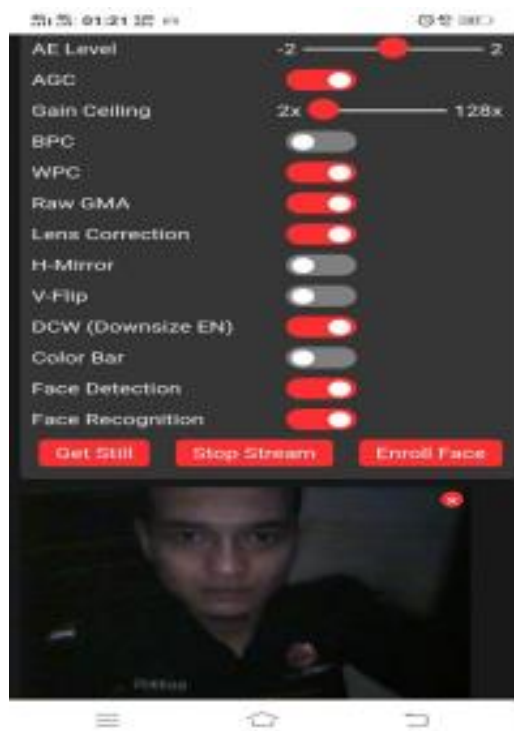

Figure 5: Recording of the face 


\section{Tool for testing}

Once the system has been completed, it is critical to test it. Esp32 will be able to recognize facial records captured on the internet. The solenoid that locks the door will be activated if the face matches the one that has been registered; else, the door will open automatically. If the face does not match what has been registered or someone else's face, the solenoid will turn off or the door will not open. This test was carried out a total of ten times.

Table 4: Testing Tools

\begin{tabular}{|c|c|c|c|c|c|}
\hline \multirow[t]{2}{*}{ Test } & \multicolumn{2}{|c|}{ Esp Camera } & \multicolumn{2}{|c|}{ Selenoid On The Door } & \multirow[t]{2}{*}{ Information } \\
\hline & Suitable & Not suitable & Open & Locked & \\
\hline 1 & $\sqrt{ }$ & & $\sqrt{ }$ & & Suitable Face \\
\hline 2 & $\sqrt{ }$ & & $\sqrt{ }$ & & Suitable Face \\
\hline 3 & & $\sqrt{ }$ & & $\sqrt{ }$ & Inappropriate Face \\
\hline 4 & $\sqrt{ }$ & & $\sqrt{ }$ & & Suitable Face \\
\hline 5 & $\sqrt{ }$ & & $\sqrt{ }$ & & Suitable Face \\
\hline 6 & $\sqrt{ }$ & & $\sqrt{ }$ & & Suitable Face \\
\hline 7 & & $\sqrt{ }$ & & $\sqrt{ }$ & Inappropriate Face \\
\hline 8 & & $\sqrt{ }$ & & $\sqrt{ }$ & Inappropriate Face \\
\hline 9 & & $\sqrt{ }$ & & $\sqrt{ }$ & Inappropriate Face \\
\hline 10 & & $\sqrt{ }$ & & $\sqrt{ }$ & Inappropriate Face \\
\hline
\end{tabular}

Based on testing, the tool uses face recognition to open the door. Faces that have been recorded on the website are detected by the Esp32 camera. The door will automatically open if the face matches one already on the list. In the opposite case, if the face does not match the one registered, the door will not open.

\section{DISCUSSION}

The face reading system for the security of the private room door is tested ten times using faces that have been saved on the webserver and faces that have not been saved, and only faces that have been recorded and saved on the webserver cause the solenoid to switch on and open the door automatically. The solenoid stays dead, thus the door will not open, but the soul of the face is not detected because it is not yet in the webserver database.

\section{CONCLUSION}

Following the design and implementation of Opening the Door Using Face Recognition Based on the Internet of Things (IoT), the tool was tested, both individually and as a whole. As a result, the door opens when the camera detects a face that matches the face recorded on the webserver, and the registered face verification data is saved to the webserver.

\section{REFERENCES}

Balkhaya, B., Ilham, D. N., Candra, R. A., Hardisal, H., \& Hasbaini, H. (2020). Designing an Arduino-based Automatic Cocoa Fermentation Tool. SinkrOn, 5(1), 92-99. https://doi.org/10.33395/sinkron.v5i1.10611

Bustomi, R. H., Hariyanto, T., \& Kunci, K. (2020). Sistem Absensi Berbasis Pengenalan Wajah dengan Metode LBPH Menggunakan Raspberry Pi. Prosiding Industrial Research Workshop and National Seminar, 11(1), $26-27$.

Candra, R. A., Ilham, D. N., Hardisal, H., \& Sriwahyuni, S. (2019). Light Control Design by Using Social Media Telegram Applications Based on Internet Of Things (IOT). SinkrOn, 3(2), 200. https://doi.org/10.33395/sinkron.v3i2.10094

Candra, R. A., Saputra, D. S., Ilham, D. N., Setiawan, H., \& Hardisal, H. (2020). The Infusion of Notification Design With an Application of Social Media Based on a Internet of Things (IOT). SinkrOn, 5(1), 129. https://doi.org/10.33395/sinkron.v5i1.10610

Dodi Sudiana, Arman D. Diponegoro, P. S. P. (n.d.). Sistem pengenalan wajah (face recognition) menggunakan metode Hidden Markov model (HMM). 148, 148-162.

Ihsan, I., Ilham, D. N., Candra, R. A., Yunan, A., \& Hardisal, H. (2020). Design of an Automatic Water Pump on a Traditional Boat. SinkrOn, 5(1), 100. https://doi.org/10.33395/sinkron.v5i1.10635

Ilham, D. N., Hardisal, H., Balkhaya, B., Candra, R. A., \& Sipahutar, E. (2019). Heart Rate Monitoring and Stimulation with the Internet of Thing-Based (IoT) Alquran Recitation. SinkrOn, 4(1), 221. https://doi.org/10.33395/sinkron.v4i1.10392

Ilham, D. N., Satria, E., Anugreni, F., Candra, R. A., \& Kusumo, H. N. R. A. (2021). Rain Monitoring System for Nutmeg Drying Based on Internet of Things. Journal of Computer Networks, Architecture, and High- 
Performance Computing, 3(1), 52-57. https://doi.org/10.47709/cnahpc.v3i1.933

Panekenan, P. W., Sompie, S. R. U. A., Kambey, F. D., Elektro, T., Sam, U., Manado, R., \& Manado, J. K. B. (2019). Implementasi Pengenalan Wajah pada Robot Beroda. Jurnal Teknik Informatika, 14(2), 193-202. https://doi.org/10.35793/jti.14.2.2019.23994

Rosa, Clara Feridda, Riski Amelia, F. M. (2019). Sistem keamanan pintu rumah dengan pengenalan wajah berbasis internet of things. Tugas Akhir.

Sahfitri, I., \& Simanjuntak, M. (2021). Penerapan Metode Viola Jones Dalam Sistem Mendeteksi Wajah.

Setiawan, I. I., Jaenul, A., \& Priyokusumo, D. (2020). P-75 Prototipe Sistem Keamanan Rumah Menggunakan Face Recognition Berbasis Raspberry Pi 4 Prototype of Home Security System Using Face. 496-501.

Suprianto, D. (2013). Sistem Pengenalan Wajah Secara Real-Time. Sistem Pengenalan Wajah Secara Real-Time Dengan Adaboost, Eigenface PCA \& MySQL, 7(2), 179-184.

Susanto, B. M., Purnomo, F. E., \& Fahmi, M. F. I. (2017). S istem Keamanan Pintu Berbasis Pengenalan Wajah Menggunakan Metode Fisherface. Jurnal Ilmiah INOVASI, 17(1), 10.

Sutarti, S., Samsuni, S., \& Asseghaf, I. (2019). Sistem Keamanan Rumah melalui Pengenalan Wajah Menggunakan Webcam dan Library Opencv Berbasis Raspberry Pi. Jurnal Dinamika Informatika, 8(2), 13-26. 